\title{
UK space policy and the politics of parliamentary debate
}

\author{
Author Accepted Manuscript \\ Journal: Space Policy (2016)
}

\author{
Dr Alexandra Kelso \\ Associate Professor of Politics \\ Department of Politics and International Relations \\ School of Social Sciences \\ University of Southampton \\ Southampton, UK. \\ a.kelso@soton.ac.uk
}

\begin{abstract}
In January 2016, a debate was held on UK space policy in the House of Commons, timed to coincide with the extravehicular activity (EVA) undertaken by British astronaut Major Tim Peake as part of his mission to the International Space Station (ISS). UK participation in ISS activities marked the culmination of a significant reorientation of government space policy in recent years, and analysis of the parliamentary debate facilitates insight into the nature of that reorientation, and the policy goals that lay at its heart. It also delineates three key themes which underpinned the parliamentary debate: the novelty of space policy as a topic of political discussion in parliament; the use of the parliamentary arena as a means through which MPs champion their constituencies as prime locations for valuable economic benefits associated with the space sector; and the portrayal of space as a source of inspiration and driver of aspiration, and as an opportunity for a vigorous space industry policy. The paper argues for the utility of parliamentary analysis as a way to enrich our understanding of the evolution of contemporary UK space policy.
\end{abstract}

\section{Keywords}

UK space policy; UK parliament; spaceport; Major Tim Peake. 


\section{Introduction}

On 15 January 2016, British astronaut Tim Peake embarked on his maiden spacewalk to conduct repairs on the International Space Station (ISS). The event attracted attention throughout the UK: there was live coverage on the BBC and other media platforms, pupils followed developments as part of their school lessons, and Peake's 'spacewalk selfie' was retweeted over fourteen thousand times. The astronaut's voyage had constituted major news ever since his launch from the Baikonur Cosmodrome in Kazakhstan, bound for the ISS on board a Russian Soyuz spacecraft. As Britain's first European Space Agency (ESA) astronaut, Peake's expedition represented a significant milestone for UK space policy, and to mark it, a debate was held in the House of Commons on the day before Peake's extravehicular activity (EVA). The debate, focused on space policy in general, was organized by backbench MPs and was of the 'take note' variety, which meant that no vote was held and it did not compel government to do anything. However, although it did not contribute to formal policy decision making processes, the debate is nevertheless worthy of examination because of the analytical lens it affords into the dynamics of contemporary UK space policy. Analysis of the debate illustrates three key insights:

- the novel nature of space policy, at least as far as most MPs are concerned, which is emblematic of what is still essentially an embryonic issue in UK politics;

- the instrumental constituency advocacy pursued by MPs in order to secure for their areas infrastructure development that is fundamental to the future success of the UK space industry;

- the use of the parliamentary arena for the articulation of aspirational public goals for the future of space policy. 
In exploring the arguments articulated during the January 2016 Commons debate, this paper seeks to advance our understanding of current UK space policy in relation to the strategic deployment of parliamentary deliberation in relation to the issue, and the role played by MPs in influencing policy discussion.

\section{The UK space policy context}

Major Tim Peake's journey to the ISS as an ESA astronaut marked the culmination of a remarkable reorientation in UK space policy, which was reflected in the parliamentary debate held in January 2016. Although analysis of that policy shift requires fuller treatment than is possible here, and has been usefully reviewed in part elsewhere [1], a few key points helpfully contextualize the change. Following the publication of the 2008 civil space strategy [2], the then Labour government announced in 2010 the creation of a UK Space Agency which, as an executive agency, would assume control of the multimillion pound budget previously dispersed throughout various government departments and research funding councils, and which would coordinate space policy and provide more coherent decision-making machinery through which the potential of space research and the space industry would be realized and its economic benefits maximized [3]. The announcement followed several years of reticence inside government regarding an agency-based approach, given the focus of the UK space industry and levels of public spending [4]. Two years later, the coalition government also increased UK contributions to the ESA, on the grounds that the space sector had enjoyed average annual growth rates of around $7.5 \%$ for the previous five years, with turnover of $£$, $9.1 \mathrm{bn}$ in 2010-11, and that investment of public money therefore made good economic sense [5]. It was this reorganization of UK space policy strategy and governance, alongside the increased public spending on the sector as a consequence of success in the commercial space industry, which made Tim Peake's participation in the ESA-ISS voyage possible, 
and which resulted in the UK joining the ISS programme and the European Programme for Life and Physical Sciences (ELIPS) [6]. Just two days before Tim Peake's mission departed Earth for the ISS, the government's Department for Business, Innovation and Skills published its National Space Policy, which outlined the UK's strategy for exploiting the strategic importance of space in terms of public services, national security, science and innovation, and the economy, and mapped how the UK would capture a greater share of the global space market and grow its successful domestic space industry [7].

Major Peake's ISS mission was highly totemic. It served as the inspirational educational and public awareness touchstone that such manned missions are uniquely positioned for, and it is in this context that the January 2016 parliamentary debate can be usefully understood. While general public knowledge and understanding of UK space projects was probably fairly limited before the Peake ISS mission [8], so too was parliamentary interest in the issue. Certainly, the House of Commons Science and Technology select committee had explored various aspects - in a 2007 inquiry into whether there was in fact a meaningful UK space policy [8]; and a 2013 inquiry into the European and UK space agencies [9] - but beyond this work, parliamentary analysis was limited. Indeed, the January 2016 debate on UK space policy was the first time in over a decade that the matter had been discussed in such a specific way by MPs [10]. Space policy therefore constituted relatively uncharted territory as far as parliamentary deliberation was concerned. In addition, the debate also occurred in the context of key investment decisions for UK space infrastructure, which were of particular interest to those MPs whose constituencies potentially stood to benefit. These two issues in particular were highly germane to the character of the debate on space policy which took place. 


\section{The novelty factor}

It is obvious from the House of Commons debate that space policy was a relatively novel topic for parliamentary discussion. The MP who introduced it, Philippa Whitford, began by reading out a message to the House from William Shatner, who expressed the hope that MPs would, in debating space, 'take the tenets of Star Trek's prime directive to universally and peacefully share in the exploration of it.' [11]. This, alongside her reference to the goodwill message sent via Twitter by George Takei, not to mention the Vulcan salute she performed during her speech, guaranteed more expansive media coverage of the event than might reasonably be expected for a backbench debate on a 'take note' motion, even one that was timed to maximize the attention being paid to the policy area as a consequence of Major Tim Peake's EVA [12]. Philippa Whitford remarked that, in their contributions, MPs were likely to stoop to using some fairly poor puns' [11], and this was indeed the case. Whitford herself managed to insert several into her contribution: she noted that the first British spacewalking astronaut had once been a research chemist for Mars; that Tim Peake's spacewalk would be 'carried out entirely on the dark side'; and that she was calling on the government minister 'to be imaginative, to be brave and to be boldly going where no Minister has gone before' (the Hansard parliamentary record notes the response: [Hon. Members: 'Ohh!']). One MP argued that the debate demonstrated that 'the force has awakened' [13], while another remarked that he would 'try to avoid the puns and conduct [him]self with gravity' [14].

The novelty factor was also in evidence in other ways. One MP who expounded the University of Glasgow's development of a laser interferometer with the ability to detect changes in distance between masses as small as ten picometers, was quizzed on whether he could explain to the House what a picometer actually was; the MP responded wryly that it was 'a measurement of picos'. Another MP explained that when he had previously 
mentioned the UK space industry in a parliamentary speech, he had been advised by senior colleagues not to do it again because he would be 'ridiculed as the spaceman of the House of Commons' [15].

It is difficult to imagine many other areas that would be approached by MPs in this humorously discursive way, at least to this extent, and that is testament to how rarely space policy has been debated in the Commons. The use of puns and jokes demonstrates the emergence onto the parliamentary deliberative agenda of space as a new, and comparatively unusual, policy issue which is likely to become increasingly important given the economic value of the space industry. What was novel in the January 2016 Commons debate is unlikely to remain so for long. In fact, while humour served as an entertaining discursive device, crucial policy issues nevertheless lay at the heart of the debate.

\section{Constituency advocacy and UK spaceport location}

The space policy motion was tabled by a member of the Scottish National Party (SNP), and most of the debate contributors were SNP MPs. This is a crucial observation for at least two reasons of direct relevance to space policy in the UK. First, at the general level, the SNP represent the vast majority of Scottish constituencies in the 2015 parliament, holding 56 out of the 59 Scottish seats, and although the SNP's fundamental position is that Scotland should become independent from the rest of the UK, their 2015 UK general election campaign strategy had at its centre the argument that, so long as Scotland remained a part of the UK, they were the party best positioned to represent the interests of Scotland inside the Westminster parliament [16]. Second, at the specific level, while Scotland has its own devolved parliament in Edinburgh (and, currently, an SNPrun devolved government), the regulation of activities in outer space, as defined by the 
Outer Space Act 1986, is a matter reserved for the UK parliament under the terms of the Scotland Act 1998 which established devolved governance. The SNP's decision to allocate precious backbench time resources at Westminster to the issue of space policy can therefore be explained in the context of it being a matter fully reserved for the UK government and thus an area where SNP MPs can usefully demonstrate their ability to 'make Scotland's voice heard' [17] on a UK issue that is of particular relevance to Scotland, as explained below.

Although the debate motion was expansive in highlighting several dimensions of space policy - scientific, cultural and technological opportunities; leveraging the Tim Peake ISS mission to capitalize on public interest in space; global space cooperation; the economic value of the space industry; and the shortlist of UK locations which could host a future UK spaceport - it is the last two issues which dominated the strategic orientation of many debate contributions, and the SNP's political purposes in pursuing the matter in the first place. Through the Space Growth Action Plan 2014-2030, the UK Space Agency was tasked with chairing the government's cross-departmental National Space Flight Coordination Group, whose programme of work included selecting a site for the UK's first spaceport, scheduled to be operational by 2018 [18]. This was fundamental to the action plan's goal of growing existing and new space businesses in the UK, particularly the highly successful satellite industry, and providing a regulatory environment that promoted enterprise and investment. As access to space was identified as a key commercial barrier, given the increasing costs to UK companies of accessing overseas launch sites for satellites, the speedy creation of UK commercial space flight capability was deemed crucial to implementing this growth strategy. A shortlist of possible spaceport locations was published in spring 2015 [19], and of the five locations identified, three were notably in Scotland [20]. The site at Prestwick, on the southwest 
coast of Scotland, was championed as an especially strong contender by the Scottish consortium supporting the bid [21], and also by Scottish media observers [22], on the grounds that it most closely met the criteria outlined by the Department of Transport in terms of a clear flight path north over the sea, and a coastal location with low population density.

It is in this context, therefore, that Philippa Whitford, as debate mover, spent most of her contribution championing Prestwick Airport, located in her constituency, as the best choice for the proposed spaceport, commending its lengthy runway, coastal location, relatively empty airspace, and on-site air traffic control centre, as well as its proximity to the technology 'catapults' found at the universities of Glasgow and Strathclyde. This point was developed by several MPs based around this area of Scotland, who noted the Scottish Centre for Excellence in Satellite Applications within the Strathclyde University Space Institute, and the role of the University of Glasgow in contributing to key space technology advances and its involvement in the ESA's Laser Interferometer Space Antenna (LISA) Pathfinder spacecraft. One debate contributor, Alan Brown MP, whose constituency bordered the Prestwick area, was clear that his singular purpose in participating was 'to give an unashamed plug to Prestwick airport' because of the economic benefits it would bring to the area, in terms of the boost in employment rates, and in the opportunities for local colleges who could deliver training in STEM subjects to meet the needs of a local space industry. MPs located in the Glasgow area also championed the Glasgow-based company Clyde Space, a supplier of small and micro spacecraft systems, and, in applauding its work in providing products for both NASA and the ESA, as well as its work for the UK Space Agency, argued that the Prestwick spaceport location would be ideally positioned for the further growth of such companies. 
In terms of the overall thrust of the space policy debate, therefore, it was essentially an SNP vehicle for applauding the success of Scotland in the commercial space industry, and for advocating the strengths of Prestwick as the best location for the UK spaceport. While MPs from the shortlisted spaceport locations in England (Newquay) and Wales (Landbedr) also spoke in the debate to champion their areas, the SNP's domination of the debate and strategic advocacy of Prestwick demonstrated their clever utilization of parliamentary deliberation in order to align Scotland explicitly with the broader goals of UK space policy.

\section{Public aspirations and the future of UK space policy}

The specific strategic political purpose of the space policy debate may have been to enable the SNP to champion the Prestwick spaceport candidacy, but it also enabled a range of contributing MPs to extol the virtues of space exploration as a driver of public aspirations in general and economic growth in particular. If parliamentary politics is too often concerned with delineating what has gone wrong with public policy, why government decisions are flawed, and lamenting the lack of public resources available for any number of worthy projects, then this particular parliamentary debate demonstrated the potential of MPs also to engage in more positive and hopeful political discussion. For example, one MP accounted for his participation in the debate, even in the absence of any space industry interests in his constituency, by explaining that 'there is something about space and the exploration thereof ... that is truly inspirational to everybody' [23]. Another noted the impact of the Major Peake mission on generating the interest of young people in science and technology, and thus shaping the next generation of professionals within the UK space sector, but also argued that, beyond concerns about an economic bottom line, 'exploration and imagination are fundamental to the human spirit, and it is difficult to think of anything comparable to space when it comes to letting 
our imaginations run riot' [24]. The overall orientation of the contributions from MPs was that space was an inherently 'good thing' because of its role as a driver of aspiration, and that UK space policy was particularly well-positioned to exploit such aspiration for the greater good. In linking aspiration to future national economic growth, MPs delineated the instrumental value of the space sector in the UK, and the utility of aspiration as a public good to be cultivated. This is a crucial point, illustrated by how often MPs referenced the economic benefits of the UK space industry as outlined by the

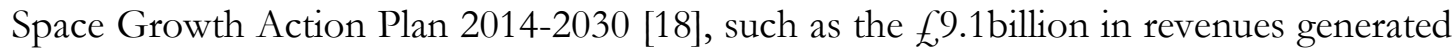
in 2010-11, the $f, 11.3$ billion in 2014 revenues, and the goal of $f, 19$ billion by 2020 , as well as the associated growth in the anticipated numbers of highly skilled jobs. One MP perfectly fused the aspirational and economic potential of space when she urged the government minister to ensure that young people would be encouraged to think of space as something that was available to them as a result of the Major Peake mission, and argued that the priority was 'to get the message out there that space is open for business'. In summing up, the minister observed that the debate had captured the mood of the nation on the eve of the Major Peake's EVA, and explained that the Prime Minister was clear that the government should 'harness the inspirational power of Major Peake's mission to inspire the next generation of scientists and engineers and to bring the country together' [25].

\section{Conclusion}

We gain a useful insight into the current landscape of UK space policy by examining the orientations of the parliamentary debate held in January 2016. Parliament may be marginal in terms of policy decision making in the UK, but it does provide a crucial deliberative arena in which policies are debated, goals interrogated, and strategies scrutinized [26]. Through debate and discussion, parliament also reflects the policy 
priorities and assumptions of political elites, and helps us to delineate the nature of both policy consensus and policy conflict. Therefore, while the specific strategy, content and direction of UK space policy is determined by the UK government, analysis of the parliamentary debate held on UK space policy affords a useful insight into the priorities and assumptions of those tasked with holding government to account for these policy choices. The analysis presented here demonstrates the novelty factor of space policy as a topic of debate amongst MPs, as well as the strategic utilization of the parliamentary arena in order to champion constituency claims on public investment opportunities associated with space policy. It also illustrates how the notion of 'space as an aspirational public good' was folded into more instrumental arguments about the economic potential of space, a crucial consideration given the government's post-2008 recovery policy and the resulting attraction of high-value, high-skilled industries such as the space sector. If the UK space industry continues to grow as predicted, then space is likely to become a more normalized aspect of parliamentary debate, and one worthy of closer analysis in order to understand the future development of the UK's space policy and how it is understood and judged by political elites at Westminster. Recent work has demonstrated that there is value in adopting a parliamentary approach to understanding space policy, such as that exploring the role of the European Parliament (EP) in the development of European Union space policy, which showed that the EP has contributed to that development even if it was not the key decision-maker [27]. This paper has sought to contribute to the development of a similar analysis in the UK context. A UK space policy research agenda which includes parliamentary analysis can usefully encompass exploration of, for example, the space policy work of relevant oversight select committees, the activities of parliament's All-Party Space Committee, and the representations made by individual MPs seeking to leverage the potential of the space industry for their own areas. In including parliamentary analysis in this way, such a 
research agenda will greatly enrich our understanding of the focus, content and intent of UK space policy. 


\section{References}

[1] R.C. Wilmouth, R. Sivalingam, The new UK civil space strategy, 2008-2012, Space Policy 24, 2 (2008), 90-94.

[2] British National Space Centre, UK Civil Space Strategy: 2008-212 and Beyond. February 2008.

[3] J. Amos, Muscular UK Space Agency launched, BBC News, 23 March 2010.

http://news.bbc.co.uk/1/hi/sci/tech/8579270.stm (accessed 27.01.16).

[4] House of Commons Science and Technology Select Committee, 2007, A UK Space

Policy, July 2007, para.47-53.

[5] P. Ghosh, Space spending to be increased by $£ 60 \mathrm{~m}$ a year, BBC News, 9 November 2012. http://www.bbc.co.uk/news/science-environment-20250533 (accessed 29.0116).

[6] Hansard, House of Commons Debates, 14 January 2016, col.1059.

[7] HM Government, National Space Policy, December 2015.

[8] House of Commons Science and Technology Select Committee, 2007, A UK Space Policy, HC 66, July 2007.

[9] House of Commons Science and Technology Select Committee, 2013, The Work of the European and UK Space Agencies, HC 253, October 2013.

[10] Hansard, House of Commons Debates, 14 January 2016, col.1030

[11] Ibid, col.1026.

[12] F. Perraudin, Star Trek endorses SNP's bid to establish Europe's first spaceport, The Guardian, 15 January 2016. https://www.theguardian.com/science/2016/jan/15/star$\underline{\text { trek-william-shatner-george-takei-snp-scotland-spaceport (accessed 17.01.16) }}$

[13] Hansard, House of Commons Debates, 14 January 2016, col.1040

[14] Ibid, col.1044.

[15] Ibid, col.1028.

[16] SNP, Stronger for Scotland: Manfesto 2015, Edinburgh.

[17] This phrase was used extensively by SNP party leader Nicola Sturgeon during the 
2015 general election campaign.

[18] Space IGS, Space Growth Action Plan 2014-2030, April 2014.

[19] HM Government, Industry backs government's spaceport plans, March 2015.

https://www.gov.uk/government/news/industry-backs-governments-spaceport-plans (accessed 01.02.16).

[20] BBC News, UK ministers issue spaceport shortlist, 3 March 2015.

http://www.bbc.co.uk/news/science-environment-31711083 (accessed 22.01.16).

[21] Spaceport Scotland, Prestwick looks spaceport frontrunner, 3 March 2015.

http://www.spaceportscotland.org/news.asp?intent=viewstory\&newsid=71504

(accessed 22.01.16).

[22] The Scotsman, Scotland leading race to host UK's first spaceport, 3 March 2015.

http://www.scotsman.com/news/scotland-leading-race-to-host-uk-s-first-spaceport-1$\underline{3990738}$ (accessed 22.01.16).

[23] Hansard, House of Commons Debates, 14 January 2016, col.1029.

[24] Ibid, col.1043.

[25] Ibid, col.1059.

[26] A.Kelso, Parliament, in: M.Flinders, A. Gamble, C. Hay, M. Kenny (Eds.), The Oxford Handbook of British Politics, Oxford University Press, Oxford, UK, 2009, pp.221-238.

[27] E. Sigalas, The role of the European parliament in the development of a European union space policy, Space Policy, 28, 2, (2012), pp.110-117. 